
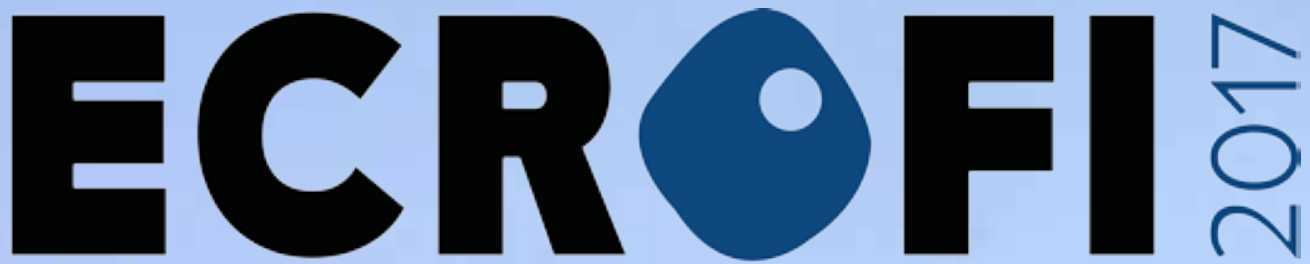

EUROPEAN CURRENT RESEARCH ON FLUID INCLUSIONS

o.

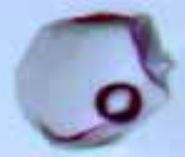

ECROFI 2017

BIENNIAL MEETING
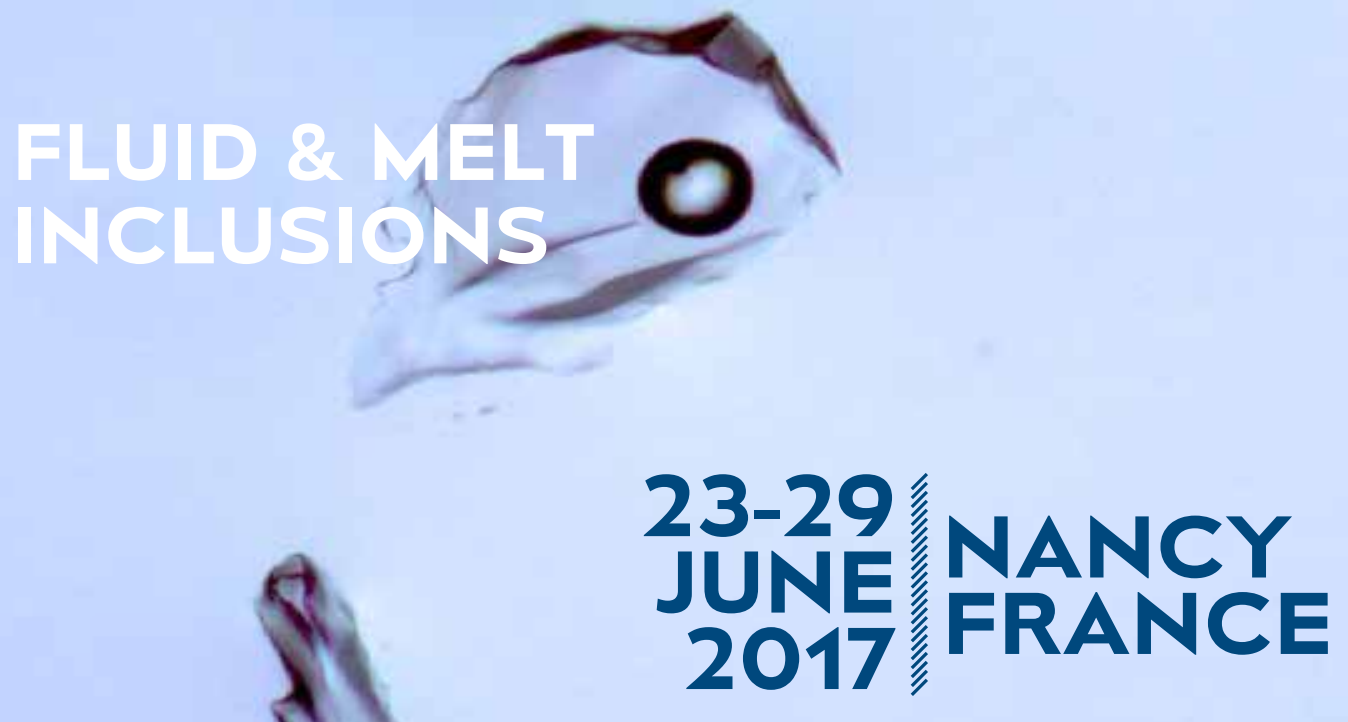

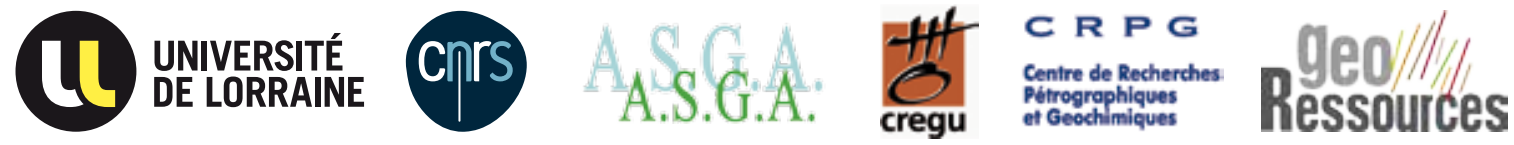


Publication manager: Jacques Pironon Layout: GeoRessources

Photos: GeoRessources

Cover photo: @ Sonya Rakotomanga-Razafimahefa June 2017 


\section{S4.T04. Vein-type graphite deposits in Sri Lanka: the ultimate fate of granulite fluids}

\section{Touret J.L.R. ${ }^{1 *}$, Huizenga J-M. ${ }^{2}$, Piccoli F. ${ }^{1}$, Kehelpannala K.V.W. ${ }^{3}$}

${ }^{1}$ Institut de Minéralogie, Physique des Matériaux, Cosmochimie, Sorbonne Université, 4 Place Jussieu, F-75005 Paris, France

${ }^{2} E G R U$, James Cook University, Townsville, Queensland, 4811, Australia

${ }^{3}$ Department of Geology, Faculty of Science, University of Botswana, Private Bag UB00704, Gaborone, Botswana ${ }^{*}$ Corresponding author: ljtouret@orange.fr

The world-best vein graphite deposits in Sri-Lanka occur scattered through the high-grade terrain of the Wanni and Highland Complexes of Sri-Lanka. The Wanni Complex (amphibolite to granulite grade) consists of $\sim 770-1100$ Ma metagranitoids, metagabbro, charnockite, enderbitic gneisses, migmatites, clastic metasediments, including garnet-cordierite gneisses, rare to minor calc-silicate rocks as well as late to post-tectonic granites (Kröner et al., 2013). Higher metamorphic grade, reaching in places UHTconditions $\left(\mathrm{T}>1000^{\circ} \mathrm{C}\right)$ characterizes the Highland Complex. Peak metamorphism occurred during the Neoproterozoic Pan-African orogeny ( 620-535 Ma), which led to the accretion of terrains in Sri Lanka and played a key role for the amalgamation of the Gondwana supercontinent (Tsunogae and Santosh, 2010). Structurally disposed in extensional fractures post-dating the Pan-African ductile structures (Kehelpannala, 1999), the graphite veins equilibrated at relatively low temperature $\left(500-600^{\circ} \mathrm{C}\right)$. However, the presence of mesoperthites indicate that graphite precipitation may have started at higher temperature.

Samples from khondalite host rocks and quartz co-precipitated with graphite from the Bogala and Kahatagana graphite mines in the Wanni Complex were studied. Host-rocks show spectacular decompression reaction aureoles around feldspars and garnet. They contain small $\mathrm{CO}_{2}$ inclusions in garnet cores or quartz in decompression reaction aureoles. Larger, highly transposed brine inclusions are more abundant and are responsible for metasomatic features (feldspar leaching and deposition) observed in the aureoles. Fluid inclusions in vein minerals are dominantly aqueous, rarely mixed $\mathrm{H}_{2} \mathrm{O}+\mathrm{CO}_{2}$. Fluid inclusions and petrographic data suggest that graphite has been deposited from fluids at decreasing pressure and temperature at relatively reduced redox conditions. Carbon isotope data indicate a dominant mantle source, mixed with small quantities of light C-bearing fluids. It has been proposed that large quantities of mantle-derived $\mathrm{CO}_{2}$ fluid have infiltrated the lower crust during the final stage of Gondwana supercontinent amalgamation (Touret et al., 2016). Formed during strong decompression at the end of a long (up to a few $10 \mathrm{Ma}$ ) period of isobaric cooling, the graphite veins in Sri-Lanka (and elsewhere in the former Gondwana) reflects the escape of these granulite fluids to higher crustal levels. In this respect, they are comparable to the quartz-carbonates mega-shear zones found in other granulite terranes (Newton and Manning, 2002). Depending on the redox conditions, former lower crustal fluids (mantle-derived $\mathrm{CO}_{2}$ and/or brines) may either result in mid to upper-crustal quartz-carbonate or graphite veins.

\section{References:}

Kehelpannala (1999) Gondwana Res. 2, 654-657.

Kröner et al. (2013) Precambrian Res. 234, 288-321.

Newton and Manning (2002) Am. Mineral. 87, 1401-1409.

Touret et al. (2016) Geoscience Frontiers 7, 101-113.

Tsunogae and Santosh 2010, Geol. Mag. 147, 42-58. 